\title{
Ankara Zincirli Cami: Korunma Sorunları ve Çözüme Yönelik Öneriler ${ }^{1}$
}

\author{
Fatma Sezin Doğruer² \\ ORCID: 0000-0002-1237-0020
}

\section{Öz}

Çalışmada, Zincirli Cami'nin (Ankara, Türkiye) tarihi, mimari üslubu, genel mimari düzeni ile yapıda görülen korunma sorunlar belirlenmiş; bozulma türleri ve muhtemel nedenleri tespit edilerek sorunların çözümüne yönelik öneriler getirilmesi amaçlanmıştır. Caminin tarihçesi hakkında kaynak taraması yapılmış; mülkiyet sahibi olan Vakıflar Genel Müdürlüğ̈̈̈nden yapının geçmiş onarımları hakkında bilgi ve belge edinilmiş olup, caminin şematik çizimleri yazar tarafından yapılmıştır. Yapı malzemelerinin karakteristik özellikleri ile bozulma türleri görsel analizlere dayalı olarak incelenmiş ve değerlendirilmiştir. 17. yüzyılda Ankara'daki konut sayındaki artış ile cami sayısında da bir artış görülmüştür. Bu yüzyıldaki cami örnekleri Ankara ekolü olarak tabir edilen dikdörtgen plan, moloz taş üzerine ahşap hatıllı tuğla veya kerpiç duvarlar, kırma çatı, ahşap minber, alçı mihrap gibi özelliklere sahip yapılardır. Zincirli Cami, Ankara'nın Altındăg İlçesi, Ulus Semti'nde Ankara üslubunda inşa edilmiş bir 17. yüzyıl camisidir. Caminin korunması kapsamında yapı malzemeleri üzerinde sıcaklık, bağıl nem, iklim koşulları gibi çevresel etkenler ile insandan kaynaklanan etkenlerden dolayı oluşan bozulmalar tanımlanmış, gerekli müdahale çeşitleri ve yeni bozulmalarm oluşmaması için çeşitli önlemler önerilmiştir. Koruma çalışmalar kapsamında laboratuvar analizleri ve raporlamalar sonucunda doğru yöntemin belirlenmesi ve önerilen yöntemlerin deneysel uygulamalar ile sinanması gerekmektedir.

Anahtar Kelimeler: Zincirli Cami, Osmanlı dönemi cami, Ankara camileri, koruma önerileri, malzeme koruma

\footnotetext{
1 Vakıflar Genel Müdürlüğü Sayı: 81007765-621.03-E.142980 Tarih: 04.11.2019 bilgileri ile izinleri alınmıştır.

${ }^{2}$ Dr., Kültür ve Turizm Bakanlığı, E-mail: sezin.dogruer@ktb.gov.tr

id ealkent (c) Kent Araştırmaları Dergisi (Journal of Urban Studies)

http://idealkentdergisi.com

Geliş Tarihi Received Date: 01.01.2021 Kabul Tarihi Accepted Date: 20.04.2021
} 


\title{
Zincirli Mosque, Ankara: Conservation Problems and Recommendations
}

\author{
* \\ Fatma Sezin Doğruer 3
ORCID: 0000-0002-1237-0020
}

\begin{abstract}
Zincirli Mosque's (Ankara, Turkey) historical information, architectural style, general architectural order and conservation problems on the structure were determined in this study. It is aimed to bring proposals for the solution of the problems by detecting types of deterioration and their possible reasons. Literature review about Zincirli Mosque's brief history was done; knowledge and documents of the previous restoration implementations were gathered from the owner institution, General Directorate of Foundations; mosque's schematic drawings were made by the author. Characteristics and types of deteriorations of the building materials were examined by visual analysis and were evaluated. With the increase in the number of houses in Ankara in the 17th century, an increase was also observed in the number of mosques. Examples of mosques in this century are the structures having characteristics such as rectangular plan, brick or mudbrick walls with wooden beams on rubble stone, hipped roof, wooden minbar, stucco mihrab, known as the Ankara Style. Zincirli Mosque is a 17th century mosque in Ulus District, Altındağ, Ankara, which was built in Ankara Style. Within the conservation of the mosque, deteriorations because of environmental factors like temperature, relative humidity, climatic conditions; and deteriorations due to human factors were defined; required types of interventions and measures were proposed to prevent new deteriorations. Within the scope of conservation studies, it is necessary to determine the correct method as a result of laboratory analyzes and reports and to test the proposed methods with experimental applications.
\end{abstract}

Keywords: Zincirli Mosque, Ottoman mosques, Ankara mosques, conservation proposals, material conservation

\footnotetext{
${ }^{3}$ Dr., Kültür ve Turizm Bakanlığı, E-mail: sezin.dogruer@ktb.gov.tr

idealkent @ C Kent Araştırmaları Dergisi (Journal of Urban Studies)

http://idealkentdergisi.com
}

Geliş Tarihi Received Date: 01.01.2021 Kabul Tarihi Accepted Date: 20.04.2021 


\section{Giriş}

Türkiye'deki kültür varlıkları gerek yapı türü, gerekse kullanılan malzemeler ve yapım sistemleri bakımından çok zengin ve çeşitlidir. Tüm geçmiş medeniyetlere ait kalıntılar, geçmiş ile gelecek arasında bir köprü olup, bu çeşitlilik ve zenginliğin bilincinde olarak bunları değerlendirmek ve sürekliliklerini sağlamak üzere korumalarını sağlamak önemlidir. Tarihi anıt ve çevrelerin "ulusal ve evrensel kültürün bir bileşeni" olarak korunması esastır (Ahunbay, 2009, s.8).

Kültür varlıkları sıcaklık, bağıl nem, yağmur, kar, iklim farkları gibi doğal koşullardan, yapı alanının özelliklerinden, yapının kendisinden (malzeme özellikleri ve teknik özellikler) ve insanların verdiği zararlardan (bilinçsizce tahrip, vandalizm, yağmalama, yoğun trafik, hatalı restorasyon, vb.) kısa veya uzun vadede etkilenmektedir. Taşınmaz kültür varlıklarının korunması kapsamında yapı malzemeleri üzerinde çevresel etkenler ile insandan kaynaklanan etkenlerden dolayı oluşan bozulmalar tanımlanmalı, müdahale çeşitleri ve yeni bozulmaların oluşmaması için gerekli önlemler belirlenmelidir.

$\mathrm{Bu}$ çalışmanın amacı Ankara üslubunda inşa edilmiş olan Zincirli Cami'nin (Ankara, Türkiye) kısa tarihçesi, genel mimari düzeni, yapım sistemi ve yapı malzemeleri gibi yapıya dair özelliklerini ortaya koymak; malzeme üzerindeki korunma sorunlarını gözlemlemek ve tanımlamak; bozulma türlerini ve nedenlerini tespit etmek ve sorunların çözümüne yönelik öneriler geliştirmektir.

\section{Yöntem}

Zincirli Cami'nin tarihçesi hakkında arşiv ve literatür araştırmaları yapılmış; mülkiyet sahibi olan Vakıflar Genel Müdürlüğünden yapının geçmiş onarımları hakkında bilgi ve belgeler edinilmiş; caminin şematik çizimleri yazar tarafından yapılmıştır. Yapı malzemelerinin karakteristik özellikleri ile bozulma türleri görsel analizlere dayalı olarak incelenmiş ve değerlendirilmiştir. Değerlendirmelerin ardından gerekli malzeme koruma yöntemleri önerilmiştir.

Bu çalışmada tespit edilen mimari düzen, koruma sorunları görsel analizler ile belirlenmiş olup, laboratuvar analizleri kapsam dişı tutulmuştur. Yapının ölçüleri Vakıflar Genel Müdürlüğü'nün 1937 tarihli onarım projesinden elde edilen verilerle ve yerinde erişilebilen ölçümlerle sınırlanmış olup, detaylı ölçülendirme yapılmamıştır. 


\section{Bulgular}

Zincirli Cami, Ankara'nın Altındağ ilçesindeki Ulus semtinde yer almaktadır. Ankara'nın tarihi kent merkezi olan bölgede yer alan cami, farklı kültür katmanları ile iç içe bulunmaktadır. Caminin batısında, Ulus Şehir Çarşısı'nın temel kazısı sırasında bulunan Geç Roma dönemine ait yolun bir bölümü bulunmaktadır (Erdoğan, Günel ve Kılcı, 2007a, s. 74). Caminin doğusunda ise eskiden iki katlı ahşap bir medrese bulunmaktayken ilerleyen yıllarda bu medrese yıkılmıştır. 1970'li yıllarda hazırlanan proje ile Anafartalar Caddesi'ne bakan cephede, cami yapısının doğusundaki avluda dükkânlar planlanmış olsa da inşa edilmemiş; cami mevcut halinde ibadet amaciyla kullanıldığından cemaat kapasitesini artırmak için avlunun üstü kapatılarak, ek duvarlarla bir namaz kılma mekânı oluşturulmuştur (Konyalı, 1978, s. 104). Cami, güney yönünde, eski adı Karaoğlan Caddesi olan Anafartalar Caddesi'ne dayanır (Kırpık vd., 2015, s.214); kuzeyinde ise Ankara Defterdarlığı ek binasına komşudur (Şekil 1).

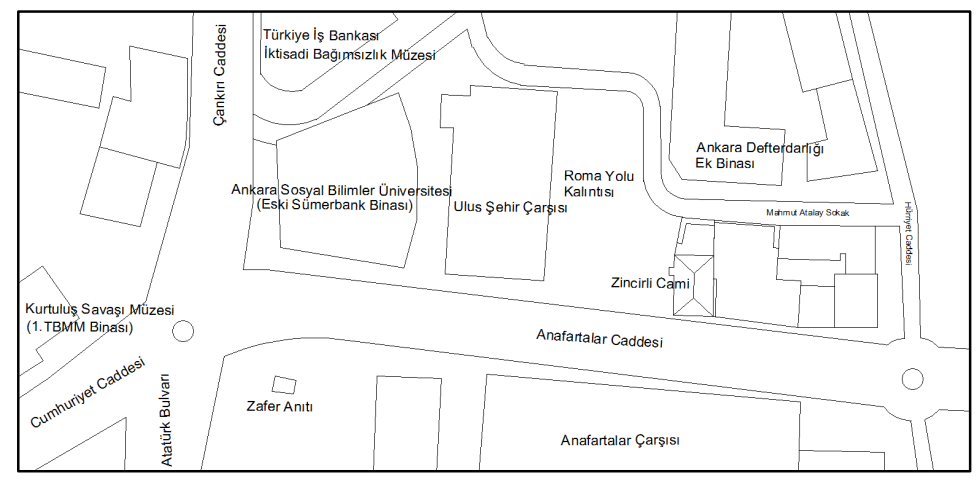

Şekil 1. Zincirli Cami Çevresinin Şematik Çizimi ${ }^{4}$

\section{Tarihi Araştırması}

Ankara, geçmişi paleolitik ve neolitik devre kadar uzanan, Roma döneminde varlığını sürdüren, Doğu Roma döneminde Hıristiyanlığın önemli bir merkezi, Türk- İslam eserlerine sahip ve Cumhuriyet' in kuruluşuna şahitlik yapmış bir şehir olmuştur (Öney, 1971, s.11-14).

Sultan Orhan Gazi döneminde Ankara'da Osmanlı hükümdarlığı başlamıştır. Sultan Çelebi Mehmed döneminde Ankara'da onarım çalışmaları ya-

\footnotetext{
${ }^{4}$ Bu çalışmada kaynak gösterilmeyen tüm çizim ve fotoğraflar yazara aittir.
} 
pılmış ve Hacı Bayram Veli'nin Ankara'daki varlığı ile şehir yeniden ihya olmuştur. 15. yüzyılda şehirde imar faaliyetleri hızlanmış, cami, hamam, imaret ve su yollarından oluşan Karacabey Külliyesi, Hacı bayram-ı Veli Külliyesi, Yeşil Ahi ve Ak Medrese, Darülhuffaz, Tabakhane, Hacı Musa, Yeğenbey gibi birçok cami bu dönemde inşa edilmiştir. Fatih Sultan Mehmed döneminde şehirde ticaretin gelişmesi amacıyla han, bedesten, çarşı ve kervansaraylar inşa edilmiştir. Kanuni Sultan Süleyman döneminde eyalet merkezi olan Ankara'da Cenabi Ahmet Paşa tarafından Mimar Sinan'a bir cami yapılmıştır (Erdoğan vd., 2007b, s.10, 29, 32, 33, 36). 17. yüzyıl ise, "Anadolu kentlerinde sosyo-ekonomik ve mekânsal ilişkilerin örgütlenmesi açısından bir dönüm noktası" olarak ele alınmaktadır (Aktüre, 1994, s. 87). Ankara merkezi ve ilçelerindeki cami ve mescitler içerisinde 14-18. yüzyıl aralıklarında Ankara ekolüne (Ankara üslubu) ait örnekler bulunmaktadır (Öney, 1971, s. 163). 17. yüzyılın sonunda, Ankara'da nüfusun artmasına paralel olarak yerleşim alanı genişlemiş, dolayısıyla cami sayısında da önemli bir artş̧ olmuştur (Aktüre, 1994, s. 103). Zincirli Cami de, Ankara'nın Ulus semtinde 17. yüzyılda yapıldığı düşünülen Ankara üslubunda bir camidir.

Cami, Ulus Meydanı'ndan Hükümet Caddesi'ne kadar birkaç sokağı kapsayan, han binaları, Kuyulu Cami, Kuyulu Kahve, İstanbul Pastanesi ile birlikte Osmanlı dönemi ve Cumhuriyet' in ilk yıllarında Karaoğlan Çarşısı olarak anılan mevkide bulunmaktadır (Ergenç, 1980, s.94). Ankara'nın Aşağ Yüz'ünde bulunan Karaoğlan Çarşısı, 17. yüzyılda Ankara'nın ana merkezi olan At Pazarı, Hanlar Bölgesi ve Bedesten'in yanında ikincil bir merkez konumundadır, 18 ve 19. yüzyılda Tahtakale Çarşısı ile birleşmiş ve Ankara'nın modern bir ticaret bölgesi haline gelmiştir (Tunçer, 2001, s.46, 47, 63). Ankara'ya demiryolunun gelmesiyle Karaoğlan Çarşısı'nın önemi artmıştır. Sonrasında, sof ve deri üretiminin azalması çarşının ticari öneminde gerilemeye sebep olmuş; Ankara'da "içine dönük bir ticaret hayatı" gelişmiştir (Erdoğan vd., 2007b, s.130, 131).

Zincirli Cami, Ankara'daki imar faaliyetlerinin hız kazandığı Osmanlı döneminde yapılmıştır (Ceylan ve Aydın, 2018, s.2). Ankara'nın Ulus semtinde yer alan Aslanhane, Hacı Bayram-1 Veli, Karacabey İmareti ve Cenabi Ahmed Paşa Külliyeleri'nin aksine bu cami bir külliye kapsamında inşa edilmemiştir (Erdoğan vd., 2007b, s.136). Yapının bitişiğindeki medrese ile birlikte Şeyhülislam Mehmed Emin Ankaravi tarafından 1687'de yaptırıldığı kabul edil- 
mektedir (Erdoğan ve Narince, 2007, s.66). 1879-1880 yılları arasındaki onarımın Ankara Valisi Hurşit Paşa 5, 1911 yılındaki onarımın Taşpınarzadeler, 1937 yılındaki esaslı onarımın ise Vakıflar Genel Müdürlüğü tarafından yaptırıldığı saptanmıştır (Yaman, 1981, s.700).

1937 ve 2001 yıllarında geçirdiği onarımlar ise cami üzerindeki kitabelerden ve kaynak taramasından anlaşılmaktadır (Kırpık vd., 2015, s. 274). Minberindeki motifler Nakkaş Mustafa tarafından, 1925'te restore edilen kapı ise Macit Usta tarafından yapılmıştır (Akpolat ve Eser, 2004, s.105).

Şeyhülislam Mehmet Emin Efendi tarafından yaptırılan eserlerden günümüze ulaşabilen tek eserdir (Kırpık vd., 2015, s.271). Kendisinin yaptırdığı diğer eserler, mescid, medrese, darü'l-kurra, mektep ve çeşmelerdir (Erdoğan vd., 2007b, s. 130, 139). Şeyhülislam, vakıf hayratının giderlerini, kendi mülkleri, satın aldığı mülkler, kiraladığı arsa ve hamamları vakfederek karşılamıştır (Kırpık, Erdoğan ve Çam, 2015, s.334). Şeyhülislam Ankaravi Mehmed Emin Efendi'nin Suluhan, Hasan Paşa Hamamı ve Şengül Hamamı'nı satın alma yolu ile gelirlerini hayratına vakfettiği kaynaklarda belirtilmektedir (Erdoğan vd., 2007b, s.139, 196).

Zincirli Cami'nin Kazasker (Kadıasker) adıyla da anıldığı söylenmektedir (Kırpık vd. 2015, s.271). Buna karşın caminin yanında eskiden Kazasker Cami adında başka bir cami yapısı bulunduğu, Şeyhülislam Mehmet Emin Efendi tarafından yaptırılan caminin aslında bu cami olduğu ve yıkıldıktan sonra kitabenin Zincirli Cami duvarına konulmuş olabileceği de ileri sürülmüştür (Eyice, 1971, s.112).

\section{Mimari Üslubu}

Osmanlı Ankara'sında cemaatin çoğalması sonucunda kimi mescidler camiye çevrilmiş ya da Selçuklu döneminde inşa edilen Alaaddin Cami ve Aslanhane Cami gibi büyük camilere ek olarak şehrin büyüyen bölümlerinde küçük boyutlu camiler inşa edilmiştir (Erdoğan vd., 2007b, s.140).

Ankara'daki 18. yüzyıla kadar inşa edilen camiler üzerine yapılan değerlendirmelerde, bir üslup birliğinden (Ankara Üslubu) söz edilmektedir. Bu üslup birliğinde moloz taş üzerine ahşap hatıllı tuğla veya kerpiç duvarlar, dikdörtgen plan, kırma çatı, ahşap minber, alçı mihrap vb. özellikler görülmektedir (Ceylan ve Aydın, 2018, s.8). Ankara Üslubu özelliklerini taşıyan camiler içerisinde Zincirli Cami de bulunmaktadır. Ankara Üslubu'na sahip cami ve mescitler plan şeması, son cemaat yeri, kadınlar mahfili kullanımı,

${ }^{5}$ Kültür ve Turizm Bakanlığı. (2019, 9 Eylül). Zincirli Camii. 
yapı elemanları ve süsleme tarzları açısından klasik üsluptan çok farklıdır (Yüksel, 2016, s.172). Klasik Osmanlı mimarisinde kullanılan kubbe bu üslup ürünlerinde görülmemektedir. Ankara'daki ahşap tavanlı camilerin aksine kubbeli camilerin sayısı oldukça azdır (Erdoğan vd., 2007b, s.140).

\section{Genel Mimari Düzeni}

\section{Mekânlar}

Yapı dıştan yaklaşık olarak $12 \mathrm{~m}$ x $20 \mathrm{~m}$ ana ölçülerindedir (Şekil 2). Dikdörtgen planlı bir yapı olan caminin girişi kuzey yönündendir (Şekil 3). Üç basamakla yaklaşılan giriş, son cemaat yerinin ortasındandır; bu revaklı k1sımdaki üç sivri kemer ve iki yandaki birer kemer ahşap doğramayla kapatılmış ve iç mekâna dahil edilmiştir. Son cemaat yerinden asıl ibadet mekânına giriş de kuzey cephenin ortasındandır ve iki yanında dikdörtgen pencereler bulunmaktadır.

İç mekân konfor koşulları, caminin kullanımı esnasında cemaat üzerinde doğrudan etkilidir. Bu nedenle karasal iklime sahip Ankara'daki caminin son cemaat yeri kış mevsiminde kullanımı açısından restorasyon sırasında camekânla kapatılmıştır (Öney, 1971, s.84). Harime girilmeden iki yanda mahfiller bulunmaktadır. Son cemaat yerinin üstünde kadınlar mahfili yer alır. Buraya, girişin sağındaki bir merdiven ile çıklır. Ahşap ayaklar üzerindeki kadınlar mahfili, harimin içine doğru bir çıkıntı yapar. Ahşap kadınlar mahfillerine 17. ve 18. yüzyıla tarihlenen Ağaç Ayak Cami, İbadullah Cami ve Sarıkadı Mescidi'nde de rastlanmaktadır (Yüksel, 2016, s. 169).

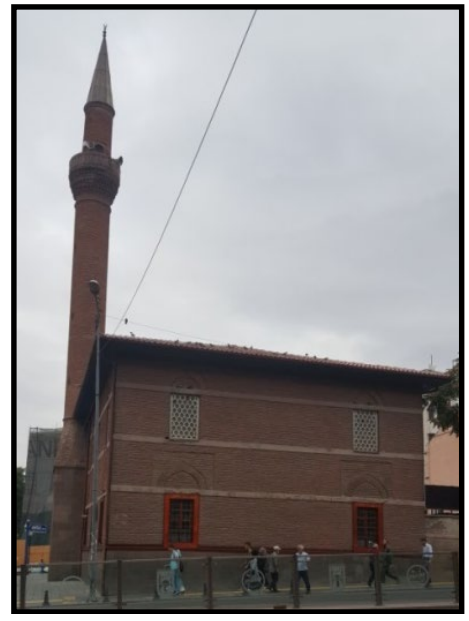

Şekil 2. Zincirli Cami 


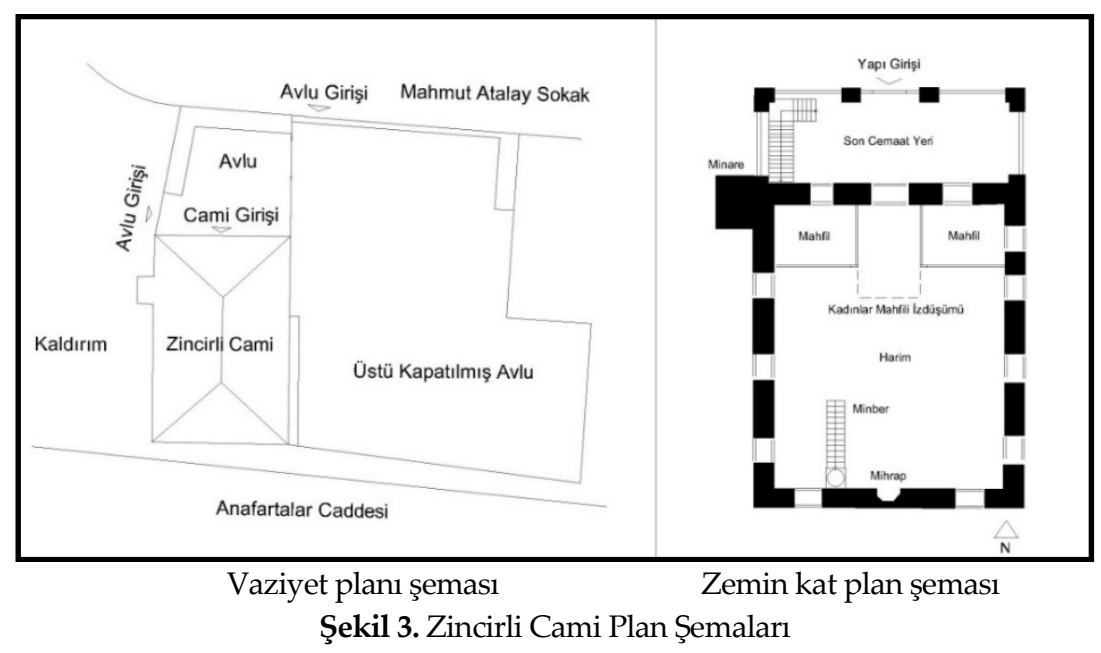

\section{Yaptm Sistemi ve Malzemeler}

Zincirli Cami yığma sistemle inşa edilmiştir. Yapı duvarlarının kerpiç örgülü ve sıvalı olduğu ancak Vakıflar Genel Müdürlüğü'nce 1937 yılında gerçekleştirilen esaslı onarımda sıva kullanılmadan tuğla ve taş kaplama malzemesi ile duvarların kaplandığı ve cephe görünümünün bu şekilde değiştirildiği anlaşılmıştır (Şekil 4). Ahşap kırma çatılıdır.
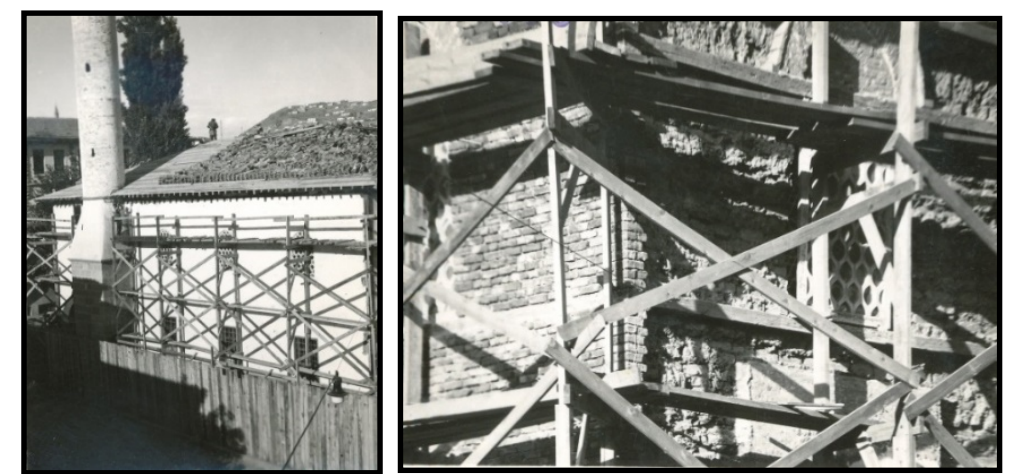

Şekil 4. Caminin 1937 Yılı Onarımı

(Vakıflar Genel Müdürlüğü [VGM], 2019)

\section{Cephe Düzeni}

Yapı cephesinde su basmana kadar kesme taş kullanılmıştır. Su basmandan çatıya kadar tuğla örülmüş olup, aralıklarla dört sıra ahşap hatıl bulunmaktadır (Şekil 5). Yapının kuzey cephesinde zemin kattaki son cemaat yerinin üzerinde kadınlar mahfiline açılan iki sıra pencere bulunmaktadır. 


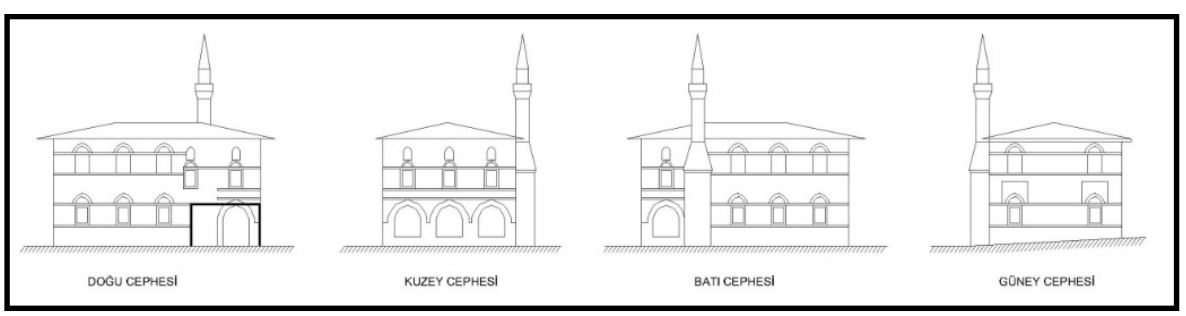

Şekil 5. Zincirli Cami cephe şemaları

Ankara üslubundaki altlı üstlü pencere kullanımı 12-20. yüzyıllar arasinda devam etmiştir (Yüksel, 2016, s.170). Caminin kuzey cephesinde üstte kemerli ve alçı şebekeli üçer, altta dikdörtgen demir parmaklıklı üçer olmak üzere toplam altı pencere bulunmaktadır. Güney cephesinde ise iki sıra halinde dört adet dikdörtgen pencere, doğu cephesinde üçer pencere, batı cephesinde ise üç sıra halinde üstte bir sıra dört adet alçı şebekeli pencere, altta bir sıra dört adet dikdörtgen pencere yer almaktadır. Dikdörtgen pencerelerde sağır kemerler kullanılmıştır.

\section{Mimari Öğeler}

Yapının kuzeybatısına bitişik olarak kare kaideli, silindirik gövdeli ve tek şerefeli minaresi yükselmektedir. Minare taş kaideli ve tuğla gövdelidir. Kaide ile gövde arasındaki geçiş kesiti üçgenlerle inşa edilmiştir. Tuğla olan silindirik gövdede üç adet taş kuşak bulunmaktadır. Üç sıra kirpi saçak ile şerefeye geçiş vardır. Şerefenin korkuluğu kesme taştan yapılmıştır. Tuğla petek bölümünün üstünde konik bir külah ve alem bulunmaktadır.

Caminin kıble duvarının sağında cuma hutbelerinin okunduğu ahşap bir minber bulunmaktadır (Öney, 1992, s.138). Minber taklit kündekari tekniğinde yapılmıştır (Yüksel, 2016, s. 164); yan aynalıklar, kafes işi kündekari tekniğindeki korkuluklar ve tahttan oluşmaktadır. Ankara'da ahşabı süslemek için 15. yüzyıldan itibaren tercih edilen kalem işleri bu camide de uygulanmıştır (Yüksel, 2016, s.171). Minber üzerinde bitkisel ve geometrik motifli boyalı süslemeler vardır.

Asıl ibadet mekânının kuzeyinde tavana kadar yükselen alçı mihrap yer alır. Yaklaşık olarak $3 \mathrm{~m} \times 7 \mathrm{~m}$ boyutlarındadır. Ankara'da 16., 17. ve 18. yüzyıllarda inşa edilen diğer camilerdeki mihraplar gibi kalıplama tekniği ile inşa edilmiş bir mihraptır (Yüksel, 2016, s.167). Mihrap, mukarnaslı kavsara ve iki yanda birer sütuncesi bulunan niş ile yazı ve geometrik süslemelere sahiptir. 1. ve 3. bordüründe neshî yazı olarak Kelime-i Tevhid yazılıdır; 2. bordürde ise geçme çokgenlerden oluşan bir örüntü vardır. Mihrap alınlığında palmet 
şeklinde üç sıra mazgal arasında neshî yazı ile işlenen Kurân sureli panolar bulunmaktadır (Öney, 1971, s. 84).

\section{Bezemeler}

Cami iç mekânının tavanı kasetleme tekniğinde yapılmıştır. Onarıma ilişkin resimlerden, 1937 yılındaki esaslı onarım sürecinde tavanların yenilendiği anlaşılmaktadır (Şekil 6). Harim tavanının ortasında, kadınlar mahfilinin üst tavanında, son cemaat yerinde ve kadınlar mahfilinin altında dört adet tavan göbeği bulunmaktadır. Harimde bordürlü altıgen göbek; Kadınlar Mahfili'nin tavanında, altında ve son cemaat yerinde bordürlü dikdörtgen panolar vardır. Göbekler üzerinde kalem işi süslemeler yer alır (Taşkan, 2016, s.76-77).
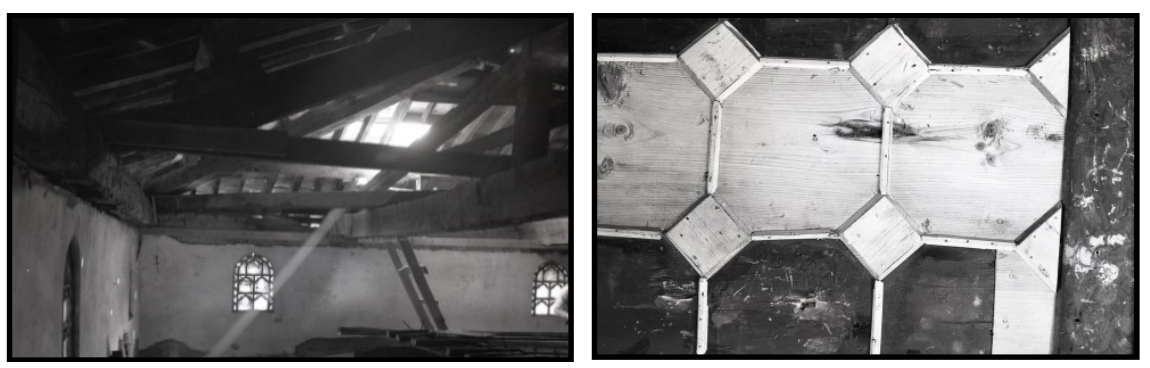

Şekil 6. Tavan yenilenmesi (VGM, 2019)

\section{Koruma Yöntemleri}

Koruma uygulamalarında temel yaklaşım olarak eser ve çevresine bütüncül olarak bakılarak, minimum düzeyde ve geri dönülemez sonuçlara yol açmayan müdahale anlayışı ile yola çıkılmalıdır. Özgün yapıya risk oluşturan faktörlerin giderilmesi, yapısal sorunların ve malzeme sorunlarının giderilmesi temel bileşenlerdir. Bunlara yönelik olarak ulusal ve uluslararası kurum ve kuruluşlarca disiplinler arası koruma çalışmaları yürütülmektedir. ${ }^{6}$ Kültürel varlıkların sürekliliğini sağlamak amacıyla yürütülen bu koruma çalışmalarında bilimsel yaklaşım bir gerekliliktir (Tapan, 2007, s.22, 23). Koruma çalışmaları kapsamında korunması gerekli taşınmaz kültür varlıklarına yönelik

\footnotetext{
${ }^{6}$ ICCROM (Uluslararası Kültürel Varlıkları Koruma ve Araştırma Merkezi) ve ICOMOS (Uluslararası Anıtlar ve Sitler Konseyi) gibi uluslararası koruma örgütleri, kültür mirasını korumaya yönelik temel yaklaşımları ve teknikleri oluşturmak, geliştirmek ve paylaşmak üzere kurulmuştur. Türkiye' de ise kültür varlıklarının korunması için gerekli tedbirleri almak, onarım ve bakımlarını yapmak, günümüz koşullarına uyumlu hale getirerek geleceğe aktarmak ile ilgili çalışmalar, uluslararası koruma ilkelerinin yanı sıra 2863 sayılı Kültür ve Tabiat Varlıklarını Koruma Kanunu ve alt mevzuatına göre yürütülmektedir.
} 
rölöve çalışması, tarihi araştırmalar, raporlamalar ve akabinde restitüsyon projesi, dönemleme, malzeme ve hasar analizleri ile restorasyon projeleri oluşturulmaktadır.

Aktif konservasyon uygulaması öncesinde disiplinler arası branşlaşmış uzmanlarca "bilinçli-ilkeli bir koruma anlayışıyla" ön çalışmalar gerçekleştirilmelidir. Koruma çalışmalarına başlanılmadan önce yapının "tarihçesi, estetik özellikleri ve değeri, teknik özellikleri ve yasal statüsü" incelenerek, yapının restorasyonunda çalışmaları yönlendirecek temel veriler elde edilmelidir (Ahunbay, 2009, s. 60).

Yöntemin yanlış seçilmesi veya yöntemin yanlış uygulanması gibi nedenlerden dolayı hatalı sonuçlar ortaya çıkabilmektedir (Eskici, 1997, s. 383). Bu yüzden koruma uzmanlarınca yapılan analizler ve değerlendirmeler sonucunda doğru yöntemin belirlenmesi ve önerilen yöntemlerin öncelikle deneysel uygulamalar ile sinanması gerekmektedir. Uygulanan yöntemlerin, malzeme üzerinde bir bozulmaya neden olmaması önemlidir. Sanat tarihi açısından önem ve belge değeri taşıyan taş̧̧ işaretleri, özgün sıvalar üzerindeki grafitiler, özgün taş, tuğla, alçı, çini ve harç gibi malzemelerin tahrip edilmemesine dikkat edilmelidir (Eskici, 2008, s.119).

Yapının fiziksel bütünlüğünde oluşan bozulmalar, yapı malzemelerinin bozulması ile doğrudan ilişkilidir. Malzemelerde görülen başlıca bozulma nedenleri olarak malzemenin kendisi, bitişik olduğu malzemeler, bulunduğu ortam ve malzemenin maruz kaldığı müdahaleler olarak sayılabilir. Örneğin, taş ve tuğla yüzeyler için örgüde eksiklik, parça kaybı, çatlak ve kırıklar, aşınma ve kirlenme gibi bozulmalar; harç ve sıvalarda kabarma, dökülme ve boya katmanları ile derz açılması görülebilir (Eskici, 2008, s.118). Restorasyon çalışmalarında "genel olarak sağlamlaştırma, bütünleme, yenileme, yeniden yapma, temizleme ve taşıma" teknikleri kullanılır (Ahunbay, 2009, s. 90).

Bu kapsamda "işlevsel ve fiziksel bütünlüğünü yitirmiş durumda olan malzemelerin değiştirilerek yenilenmesi" de gerekli bir uygulamadır (Eskici, 2008, s.118). Malzeme koruma uygulamalarından biri olan tamamlama işlemlerinde ise zaman içinde "farklı malzeme, benzer özellik", "benzer malzeme, benzer özellik", "aynı malzeme, aynı özellik", "farklı malzeme, farklı özellik" veya modern malzeme kullanılarak tamamlama prensipleri ile yapılan uygulamalar olmuştur. Önemli olan esere zarar vermeden ve algıda yanıltmaya kaçılmadan gerçekleştirilecek uygulamalardır (Şener, 2015, s.144-151). Temizlik işlemleri ise malzeme yüzeyine doğrudan bir uygulama olduğu için özgün malzemeyi aşındırmayan, yapısal zayıflık oluşturmayan, yüzeyde tuzlanma, sararma veya lekelenme gibi yeni oluşumların üremesine olanak 
sağlamayan bir metodun seçilmesi gerekir. Seçim sırasında temizlenecek malzemenin cinsi, korunmuşluk durumu, kir tabakasının niteliği ve yüzey genişliği belirleyici rol oynayacaktır. Atomize su ile temizlik (nebulizasyon), buhar ile temizlik, emici killerle paketleme ve kimyasal paketleme gibi islak temizlik yöntemleri ile mekanik temizlik, lazer ile temizlik ve kontrollü mikro kumlama gibi kuru temizlik yöntemleri kullanılmaktadır (Eskici, 2009, s. 775783).

Aktif korumanın yanında önleyici koruma da uygulanmalıdır. Bozulmalara neden olan nem problemleri (yağmur suyu, yükselen nem, yoğunlaşma) gibi etkenlerin ortadan kaldırılması gelecekte aynı bozulmaların tekrar oluşmasını engelleyecektir. Yüzeye uygulanacak koruyucu aplikasyonu da malzemede su, tuz veya asidin penetrasyonunu azaltacak; fiziksel ve kimyasal bir koruma sağlayacaktır (Eskici, 1997, s.389, 340).

\section{Yapıda Görülen Bozulmalar ve Koruma Önerisi}

Tarihi çevrelerin modern çağın getirdikleri ile değişerek özgünlüğünü kaybetmesi kent kimliğinin kaybolmasına sebep olmaktadır. İklim şartlarından dolayı bir gereksinim haline dönüşen kapalı mekânlar, cemaat kapasitesini artırmak için bu yapıda da zamanla gerekli hale gelmiştir. Bu amaçla caminin avlusunun üzeri bir örtü ile kapatılmış; son cemaat yerindeki kemer açıklıkları ise ahşap doğramalar ile kapatılmıştır. Yapılan düzenleme ve ilaveler, caminin çevresinin özgünlüğünün zedelenmesine neden olmakla birlikte kaldırılabilir nitelikte olması nedeniyle bu örtünün muhafaza edilmesinde sakınca görülmemektedir.

Yapının 19. yüzyılın sonlarından itibaren çok sayıda basit ve esaslı onarım geçirdiği anlaşılmaktadır. Halen cami olarak kullanılmakta olduğundan yapı bakımlı durumdadır. Boya, badana ve çatı onarımı gibi basit bakım ve onarımları yapılmaktadır. Alaturka kiremitlerin bakım ve onarımlar esnasında birkaç kere yenilendiği anlaşılmıştır. Yapıda ayrıca herhangi bir strüktürel sorun gözlemlenmemiştir.

\section{Yapı Malzemelerinde Görülen Bozulmalar ve Koruma Yöntemleri}

Zincirli Cami'nde de yapı malzemesi olarak taş, tuğla, ahşap, metal, cam, alçı ve kiremit kullanılmıştır. Ahşap malzemeler üzerinde boyalı süslemeler uygulanmıştır. Caminin trafiğin yoğun olduğu bir cadde üzerinde yer almasından dolayı hava kirliliği, egzoz gazları gibi etkenler malzeme bozulmalarında 
etkin bir rol oynamaktadır. İnsan kaynaklı ve yakın dönem onarımlarından kaynaklanan bozulmalar da yoğun olarak görülmektedir.

\section{Taş Bozulmaları ve Koruma Önerileri}

Yapı, geçirdiği bir restorasyon sırasında, su basman hizasına kadar andezit kesme taş ile kaplanmıştır. "Magmanın derinlik kayacı olan diyoritin volkanik tipi" olan andezitin, çatlaksız, yoğunluğu ve feldispatları ayrışmamış olanları yapı malzemesi olarak kullanılmaya uygun olduğu bilinmektedir (Küçükkaya, 2004, s.14).

İç yüzünde yaygın bir uygulama olan moloz taş kullanılmaktadır (Şekil 7). Dikdörtgen kesilmiş taşlar yatay olarak sıralanmıştır. Beden duvarlarında eşit boyutlarda (yaklaşık $33 \mathrm{~cm} \times 50 \mathrm{~cm}$ ) taş sıraları kullanılmıştır. Minare kaidesinde ise $60 \mathrm{~cm} \times 80 \mathrm{~cm}$ boyutlarında taşlar kullanılmıştır. ${ }^{7}$ Ayrıca giriş açıklığında kemerlerde ve minare boyunca kuşaklarda da taş kullanılmıştır (Şekil 8).

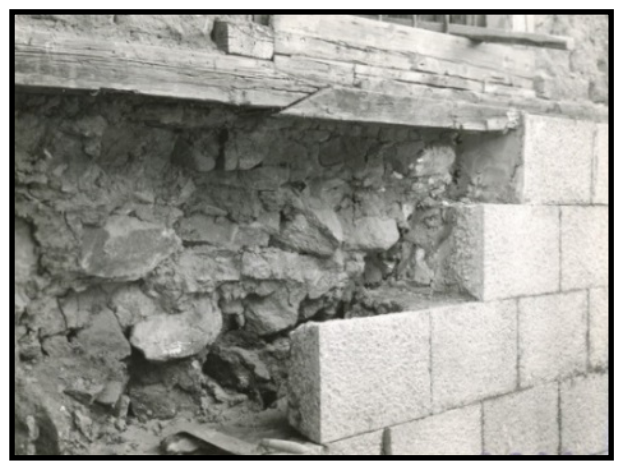

Şekil 7. Cami duvarı iç dolgusu (VGM, 2019)
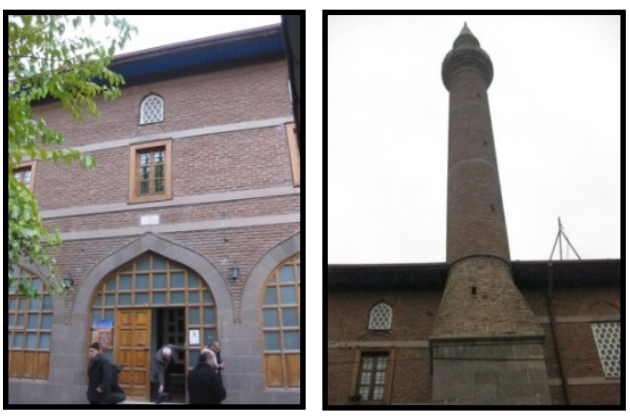

Şekil 8. Taş kullanımları

\footnotetext{
${ }^{7}$ Kullanılan taş malzemelerin derinlikleri ölçülememiştir.
} 
Yapının taş yüzeylerinde örgüde eksilme veya büyük parça kaybı görülmemekle birlikte, taş elemanlarda kılcal çatlak, yüzeysel aşınma, atmosferik kirlenme ve nem kaynaklı siyah tabaka, grafiti ve plastik onarımdan kaynaklanan bozulmalar (Şekil 9) görülmektedir.
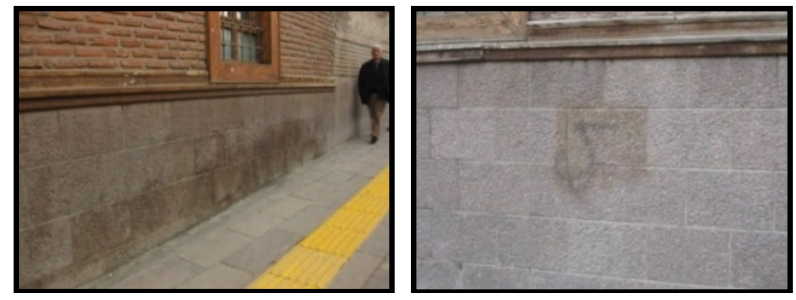

Şekil 9. Taş bozulmaları

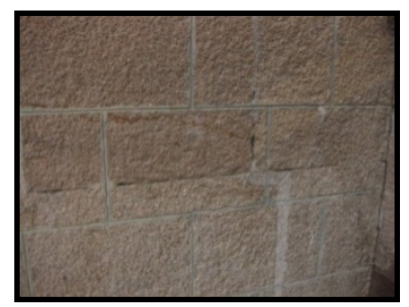

Yapının özgününde olmayıp restorasyon sırasında eklenen taş kaplama malzemesi dönem eki olarak korunmalıdır. Ancak, yakın dönem onarımları kapsamında minare kaidesindeki büyük boy taşlara, beden duvarlarındaki taşların boyutuna uygun yeni derz izleri oluşturmak amaciyla zarar verilmiştir. Koruma önerisi olarak parça kaybı olan taşlarda taş tozu, hidrolik ya da sönmüş kireç ile plastik tamamlama ve derz izi oluşturulan minare kaidesindeki taşlarda ise özgününe uygun taşlarla yenileme önerilmektedir. Korumaya yönelik bir müdahalede bulunulmadan taşların mineral yapısı, gözenekliliği, geçirimliliği analizlerle belirlenmelidir. Restorasyon sırasında kullanılacak malzemenin fiziksel ve kimyasal özelliklerinin malzemenin yap1sına uygun olup olmadığ tespit edilmelidir (Eskici, 1997, s.383). Çatlaklara hidrolik kireç ve reçine kullanarak enjeksiyon yapılması uygun olacaktır. Çimentolu karışım kullanımı özgün duvar bölümlerinde tuzlanma gibi sorunlara neden olacağ 1 için tercih edilmemelidir.

Yoğun trafik bulunan bir cadde üzerindeki bu yapıda ince bir kir tabakası görülmektedir. Uygun temizlik yöntemi, yüzeyde kirlilik olan alanlarda büyüklüğe, taşın cinsi ve niteliğine göre seçilmelidir. Nitekim tarihi yapılarda yürütülen temizlik çalışmalarında her yüzeye ve koşula uyan tek bir temizlik yöntemi bulunmamaktadır. Yapılacak deneysel uygulamalar ile malzeme ve bozulma türü için en uygun yöntem belirlenebilecektir (Eskici, 2009, s. 773). Camide su basmana kadar olan taş yüzeyler için fırçalarla mekanik temizlik veya mikro kumlama uygulanabilir. Mikro kumlama uygulamasında basınç, püskürtülen kilin sertliği, kirin kalınlığı, püskürtülen granül boyutu, uygulama süresi ve uygulama mesafesi parametreleri dikkate alınarak, uygun malzeme ile (taş tozu, cam tozu, meyve kabuğu tozu, meyve lifi tozu vb.) kontrollü kumlama yapılmalıdır (English Heritage, 2012, s.190). Bu şekilde 
yüzeye püskürtülen malzeme, yüzeyi mekanik olarak temizleyecektir. Grafiti yapılmış küçük alanlarda ise kimyasal paketleme ile temizlik yapılmalıdır. Bu uygulama sonrasında yumuşayan tabakanın su ile temizlenmesi ve gerekirse işlemin tekrarlanması önerilir. Taş yüzeyinde zamanla doğal olarak oluşan bir film tabakası olan patina, taş üzerinde koruyucu bir etkiye sahip olduğu ve kirlilikle karıştırılmaması gerektiği unutulmamalıdır. Bu tabakanın tamamen kaldırılması taş yüzeyini bozulmalara daha açık hale getirecektir (Küçükkaya, 2004, s.97, 98).

Malzemelerde görülen aşırı bozulma durumlarında temizlik uygulamaları öncesinde bir ön sağlamlaştırma yapılması yerinde olacaktır (Eskici, 1997, s.384). Tamamlama ve temizlik uygulamalarının sonrasında taş yüzeyler üzerine su itici ürünler, nanoteknolojik ürünler, siloksan veya silan esaslı ürünler kullanılarak yüzey koruma uygulanabilir. Kullanılacak ürünlerin renk değiştirmemesi (şeffaf olması), su geçirimliliğinin olmaması yanında buhar geçirimliliğinin olması önemlidir.

\section{Tuğla Bozulmaları ve Koruma Önerileri}

Caminin beden duvarlarında ve minaresinde kırmızı tuğla kullanılmıştır. Tuğlaların üzeri sıvasız bırakılmıştır. Yüzeyi yaklaşık $4 \mathrm{~cm}$ x $20 \mathrm{~cm}$ boyutlarındaki tuğlaların orta derecede gözenekli olduğu gözlemlenmiştir. ${ }^{8}$

Pencerelerin üstlerinde tuğladan hafifletme kemerleri kullanılmıştır. Minarenin gövdesi silindirik tuğladan yapılmış olup, minare kaidesinden gövdeye geçişte tuğlalarla üçgen bir kuşak oluşturulmuştur. Yapının tuğla elemanlarında örgüde eksilme görülmemekle birlikte, parça kayıpları, kirlenme ve kılcal çatlaklar, yüzeysel aşınmalar ve özellikle minarenin geçiş kesitinde derin aşınmalar görülmektedir (Şekil 10).

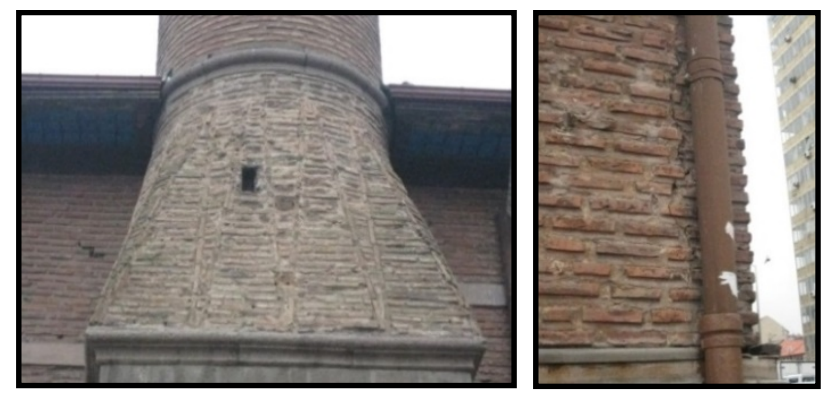

Şekil 10. Tuğla bozulmaları

\footnotetext{
${ }^{8}$ Kullanılan tuğla malzemelerin derinlikleri ölçülememiştir. Uygulama öncesinde tuğlaların kimyasal içeriği ve pişirilme derecesi laboratuvar ortamında analiz edilmelidir.
} 
Koruma önerisi olarak öncelikle parça kaybı olan tuğlalarda aşınan alanın büyük olduğu bölümlerde tuğla ile, küçük olan alanlarda tuğla tozu, hidrolik veya sönmüş kireç ile tamamlama yapılmalıdır. Tamamlamalar yapılırken yüzey tarama, doku, renk tonu farkı gibi çeşitli belirtme teknikleri kullanılarak yeni malzemenin özgün malzemeden ayırt edilmesi gereklidir. Tuğla üzerinde kirlenme olan yerler için düşük basınçlı, granül boyutu küçük malzeme püskürtmeli kontrollü mikro kumlama uygulanabileceği söylenebilir, ancak deneysel uygulamalar sonucunda en uygun temizlik yöntemi seçilecektir. Tamamlama ve temizlik uygulamalarının sonrasında yüzey üzerine renk değiştirmeyen, su geçirmez, buhar geçirimliliği olan yüzey koruma malzemeleri önleyici koruma amacıyla uygulanmalıdır.

\section{Harç / Sıva Bozulmaları ve Koruma Önerileri}

Harç malzemesi, yapıda duvar içlerinde, taş ve tuğla kaplama yüzeylerinde derz aralarında kullanılmıştır. Kesme taşlar arasındaki derz kalınlığı son derece ince olmasına karşın tuğlalar arasındaki derz kalınlığı yaklaşık bir tuğla yüksekliğindedir (Şekil 11). Duvarların dış yüzünde duvar örgüsü üzerinde sıva bulunmayıp sadece hatıl üzerinde bir sıva tabakası uygulanmıştır.
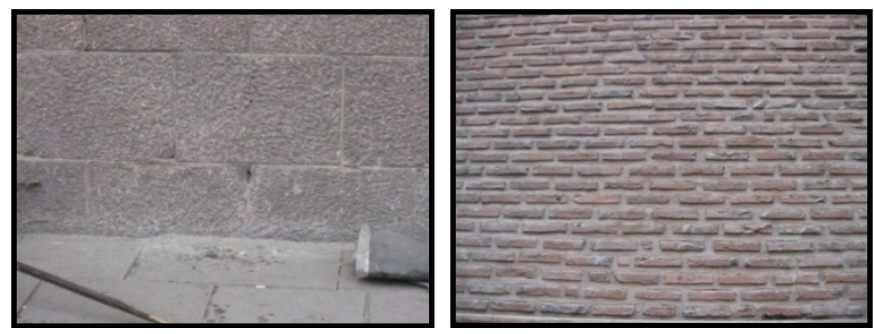

Şekil 11. Derz aralarında harç kullanımları

Derz aralarındaki harçlarda çevresel faktörlerden kaynaklı dökülme ve aşınma görülmektedir (Şekil 12). Malzemelerde ayrıca insan kaynaklı problemler de bulunmaktadır (Şekil 13). Elektrik/telefon tellerinin yapıya monte edilmesi sonucu bozulan harcın farklı nitelikte harç malzemesi ile tamamlandığı görülmüştür. 


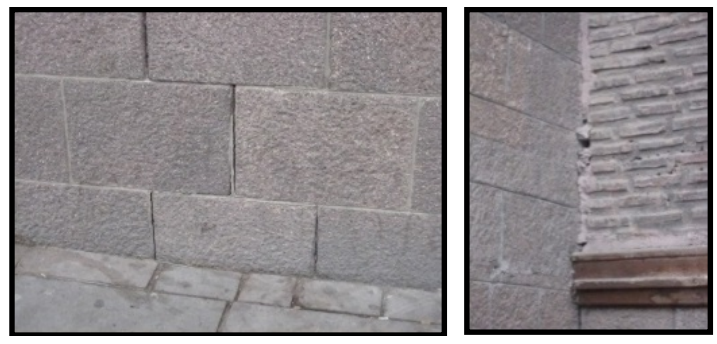

Şekil 12. Harç bozulmaları

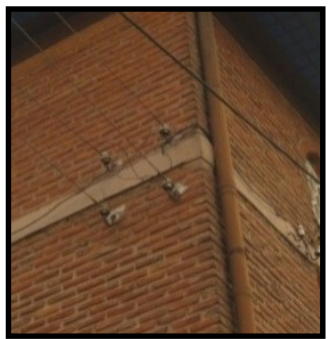

Şekil 13. İnsan kaynaklı problemler

Harçlardan sağlam olanlar korunmalı, çimentolu harçlardan yapı arındırılmalıdır. Dökülenlerin yerine özgün harç ile benzer nitelikte karışım oluşturularak uygulama yapılmalıdır. ${ }^{9}$ Hidrolik veya sönmüş kireç, taş tozu veya kırığ1 ve agrega bulunan harç/sıva karışımı örnek karışım olarak kullanılabilir. Onarım harcı ve sıva numunelerinin renk ve doku çalışmaları ile deneysel uygulamalarının yapılması önemlidir. Hatıl üzerindeki sıva tabakası raspa edilmeli ve gerekli ahşap koruması yapılmalıdır.

\section{Ahşap Bozulmalarn ve Koruma Önerileri}

Camide taş örgünün tuğla örgüye bağlandığı hattan itibaren duvar yüksekliğince belli aralıklarla tekrarlayan dört sıra ahşap hatılda, tavanda, kapılarda, pencerelerde, çatıda, saçak altında ve minberde ahşap malzeme kullanılmıştır (Şekil 14).

\footnotetext{
${ }^{9}$ Duvarlardaki özgün harçların kimyasal içeriği, bağlayıcı agrega oranları analizlerle tespit edilmelidir.
} 

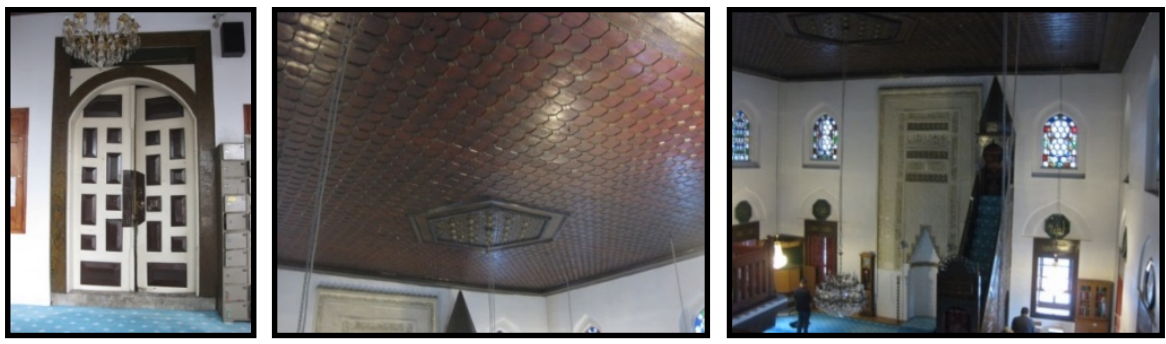

Şekil 14. Ahşap kullanımları

Yapıdaki ahşap elemanlarda parçalanmalar, kirlenmeler ve boyada renk değişimleri görülmektedir (Şekil 15). Ahşap malzemelerde bozulma durumlarının mekanik, elektrikli, optik, akustik, termografik, radyografik, nükleer magnetik, kimyasal ve biyolojik yöntemlerle tespit ve teşhis edilmesi gerekir (Nazire, 2010, s.84). Analizler sonucu tespit edilen biyolojik bozulma türüne göre, ahşap malzemelerde fırça ile kontrollü temizlik, gerekli ise enjektör ile ilaçlama yapılması, biyolojik etkenden arındırılan malzemenin üzerindeki boşluklara ise reçine, solvent ve ahşap tozu veya katı madde içeren dolgu malzemesi sürülmesi önerilir. Ahşap elemanda dayanıklılı̆̆a neden olacak çürümenin var olması halinde, emprenye yapılması gerekmektedir. Ahşap eleman eğer fiziksel bütünlüğünü yitirmiş durumda ise yeni malzeme ile değiştirilmesi de uygulanabilir.
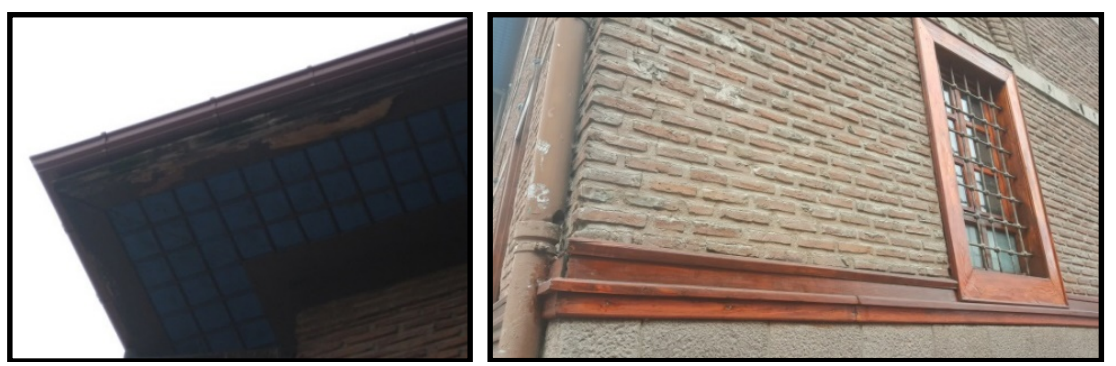

Şekil 15. Ahşap bozulmaları

Yapılan görsel analizlere göre, koruma amacıyla yüzeylere uygulanan yoğun vernik tabakası bazı bölümlerde parlamalara, renk değişimlerine ve motiflerin tanımlanmasının zorlaşmasına neden olmuştur. Ahşap üzerindeki sıva tabakası, yağlı boya tabakası ve vernik uygun yöntemle yüzeyden arındırılmalı, yüzey raspası yapılarak boya katmanları ortaya çıkarılmalıdır. İhtiyaç olması halinde yukarıda belirtilen biyolojik bozulmalara karşı koruma 
önerileri uygulanmalı ve koruma uzmanınca belirlenecek renk ile ahşap üzerine boya ve paraloid içeren sağlamlaştırıcı madde uygulaması yapılması önerilmektedir.

\section{Boyalı Süsleme Bozulmaları ve Koruma Önerileri}

Ahşap tavan üzerinde ve pencerelerde boyalı süslemeler bulunmaktadır (Şekil 16). Bu süslemelerde çiçek ve yaprak motifleri kullanılmıştır. Boyalı süslemelerin üzerine vernik uygulanmıştır. Vernikler kalem işlerinin renginde koyulaşmaya neden olmuştur. Süslemelerde ayrıca kirlenmeler görülmektedir. Özgün boyalı süslemeleri açığa çıkarmak, vernik tabakası ve kirlenmeleri temizlemek için çok itinalı ve orijinal yapıyı bozmayacak nitelikte kimyasal temizlik kullanılmalıdır. Gerektiği takdirde yüzeyin tozdan arınd1rılmasını takiben su bazlı ve mineral kökenli malzemeler kullanılarak nötr renkte rötuş uygulanabilir.
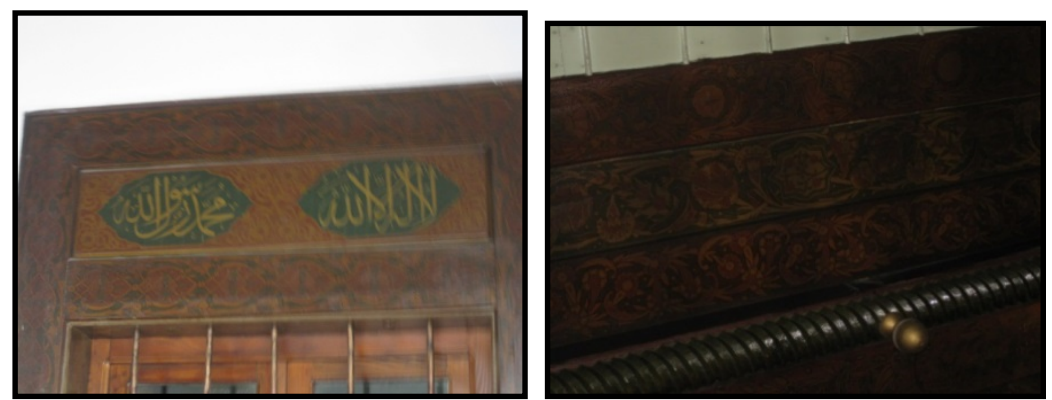

Şekil 16. Boyalı süslemeler

\section{Metal Bozulmalarn ve Koruma Önerileri}

Cephelerde alt siradaki pencerelerde metal parmaklıklar ve su olukları bulunmaktadır (Şekil 17). Yapının metal elemanlarında oksidasyon ve boya katmanları görülmektedir. Metal üzerindeki yağlı boya tabakası 1sı tabancası ile yüzeyden arındırılmalı ve antipas uygulaması yapılmalıdır.
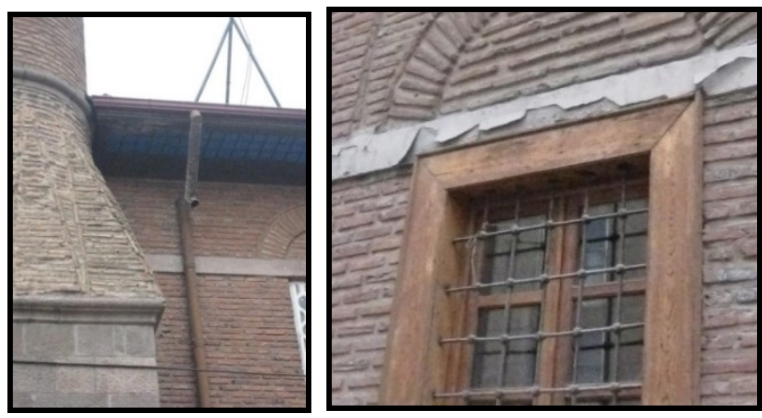

Şekil 17. Metal kullanımları 


\section{Cam Bozulmalarn ve Koruma Önerileri}

Pencerelerde hem renksiz hem de renkli camlar kullanılmıştır. Çift cidarlı pencerelerde dişta sade olarak renksiz ve geometrik kesimli camlar, içeride ise renkli ve değişik desenlerde camlar kullanılmıştır. Bu cam elemanların bir kısmında kırıklar ve boyalarda renk değişimleri görülmektedir (Şekil 18). K1rık olan camlar yenisi ile değiştirilmeli, cam değişimlerinde restorasyona özel cam tercih edilmelidir (Hasdemir, 2014, s. 64). Cam üzerindeki kirler ise yumuşak kil firça ve su temizlenmelidir.

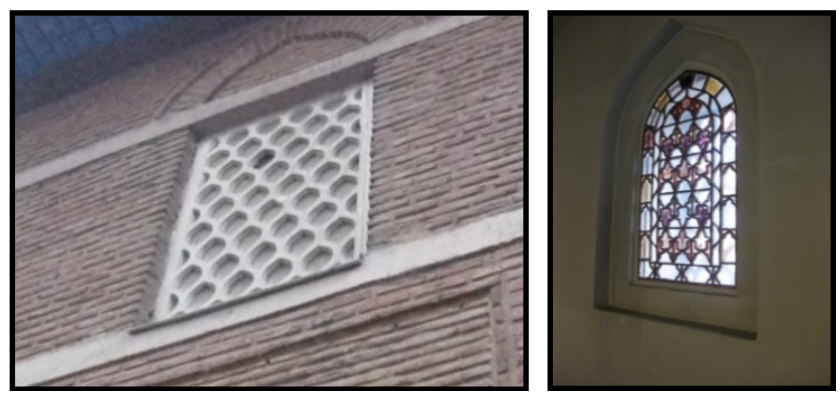

Şekil 18. Cam bozulmaları

\section{Alçı Bozulmaları ve Koruma Önerileri}

Kolay elde edilmesi ve işlenebilmesi, düz yüzeyler dışında da uygulanabilir olması bakımından alç, mimaride sıklıkla kullanılmaktadır. Zincirli Cami'nin de geçirdiği bir onarımda iç mekân duvarlarına alçı sıva uygulandığı anlaşılmıştır (Şekil 19). Ayrıca pencerelerde alçı şebeke ve kuzeydeki mihrapta alçı kullanılmıştır (Şekil 20). Yapıdaki alçı şebekelerdekılcal çatlaklar ve mihrapta çeşitli boya katmanları görülmektedir. Mihrabın kenar bordürlerinin belli bir yüksekliğe kadar bozulup düz sıva ile sıvandığı, palmetlerinin kırıldığı, boya tabakaları yüzünden motiflerin seçilemediği belirlenmiştir (Eskici, 2001, s.136).

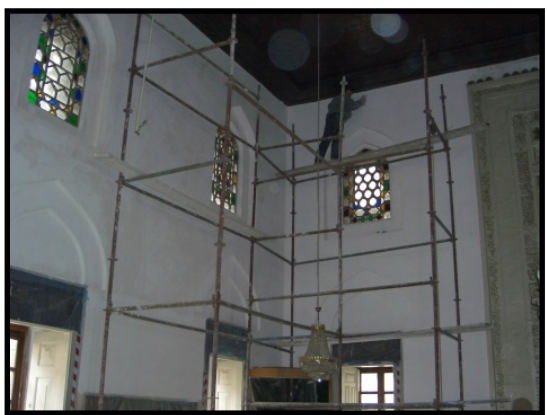

Şekil 19. Onarımda alç uygulaması (VGM, 2019) 


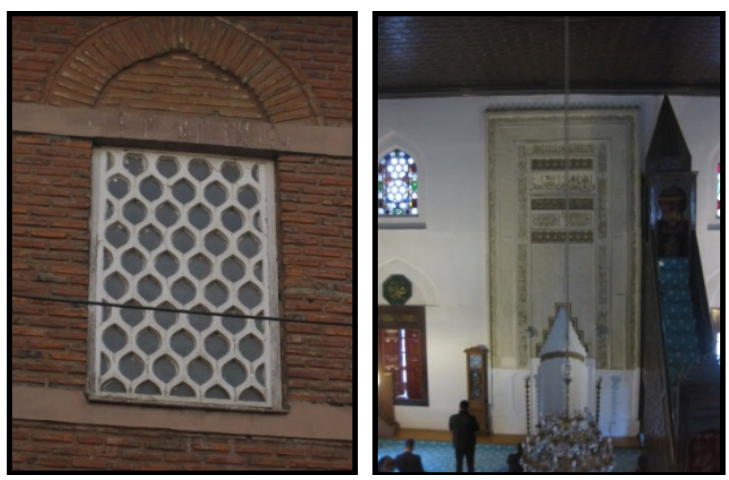

Şekil 20. Alçı kullanımları

İç mekândaki alçlar üzerindeki boyalar raspa edilerek boya katmanları tespit edilmelidir. Alçı üzerindeki çatlaklar sağlamlaştırıcı reçine ve alçıdan oluşan karışım hazırlanarak doldurulmalıdır. Alçıda dökülme tespit edilmesi halinde kireç ve alçıdan oluşan onarım harcı ile dolgu yapılmalıdır. Cephede kullanılan alçı yüzeylere ise çevresel etmenlerden koruma amacıyla su itici bir yüzey koruyucu uygulanması önerilmektedir.

\section{Sonuçlar}

İlk inşa tarihi 17. yüzyıla uzanan Zincirli Cami 19, 20 ve 21. yüzyıllarda çok sayıda onarım geçirmiş ve şu an ibadete açlk durumdadır. Caminin halen kullanılması nedeniyle periyodik olarak bakımdan geçtiği ve 1937 yılında yapının geçirdiği esaslı onarım ile caminin cephesinin tamamen değiştiği anlaşılmıştır.

Yapının bulunduğu alan Roma, Osmanlı ve Cumhuriyet dönemlerine ait eserleri bir arada bulunduran bir sit alanı olması bakımından önemli bir yere sahiptir. Cami ve çevresine bütüncül olarak bakılmalı ve bu ortamın değerleri doğru şekilde algılanmalıdır. İklim şartlarından ve cemaat kapasitesini artırmak amacıyla kapalı mekâna dönüştürülen avlu düzenlemesi ve ilaveler, caminin çevresinin özgünlüğünün zedelenmesine neden olmuştur. Ancak, bu uygulamaların bir ihtiyaç olduğu gerçeği ve kaldırılabilir nitelikte olması nedeniyle bu şekilde muhafaza edilmesinde sakınca görülmemektedir.

Cephe taş kaplamasında yapılan hatalı uygulamalar, mekân içinde ve cephede kat kat yapılan boyama ve vernikler sonucunda ahşap elemanlar ve alçı mihrapta da özgün görünüm bozulmuştur.

Görsel analize dayalı gerçekleştirilen bu çalışmada özellikle malzeme bozulmalarına yönelik koruma önerilerinde bulunulmuştur. Yapılması önerilen malzeme koruma çalışmaları kapsamında yapının mevcut durumunun 
incelenmesi, bozulma etkenlerinin araştırılması ve tespit edilmesi ile bunlara müdahale edilmesi söz konusudur. Bu uygulamalara geçilmeden önce bilimsel esaslara göre belgeleme, tarih ve restitüsyon araştırmaları ile projelendirme çalışmaları yapılması gerektiği unutulmamalıdır.

Projelerin hazırlık aşamasında önemli bir çalışma malzeme korumaya dair analizlerin yapılarak raporlanmasıdır. Çalışmada kapsam dışı tutulmuş olan, yerinde tahribatsız yöntemlerle malzeme analizleri ve arkeometrik çalışmalar sayesinde malzemenin fiziksel ve kimyasal özellikleri, malzeme bünyesindeki değişimler ve bozulmalar hakkında bilgi edinilecektir. Şüphesiz ki, koruma biliminde sağlıklı sonuçlar elde edebilmek için çeşitli bilim dallarının bir arada bulunduğu interdisipliner bir çalışma ortamına ihtiyaç vardir.

Önerilen koruma yöntemlerinin uygulanmasını takiben, bozulmalara neden olabilecek problemlerin ortadan kaldırılması amacıyla yüzeye uygulanacak koruyucu, malzemede su, tuz veya asidin girişimini azaltacaktır. Uygulamaların bitiminden sonra ise periyodik bakımlar ile malzemenin ömrü uzatılmalı, sürdürülebilir restorasyon uygulamaları yapılmalıdır. 


\title{
Extended Abstract
}

\section{Zincirli Mosque, Ankara: Conservation Problems and Recommendations}

\author{
$*$ \\ Fatma Sezin Doğruer \\ ORCID: 0000-0002-1237-0020
}

Zincirli Mosque's (Ankara, Turkey) historical information, architectural style, general architectural order and conservation problems on the structure were determined in this study. It is aimed to bring proposals for the solution of the problems by detecting types of deterioration and their possible reasons. Literature review about Zincirli Mosque's brief history was done; knowledge and documents of the previous restoration implementations were gathered from the owner institution, General Directorate of Foundations; mosque's schematic drawings were made by the author. Characteristics and types of deteriorations of the building materials were examined by visual analysis and were evaluated. With the increase in the number of houses in Ankara in the 17th century, an increase was also observed in the number of mosques. Examples of mosques in this century are the structures having characteristics such as rectangular plan, brick or mudbrick walls with wooden beams on rubble stone, hipped roof, wooden minbar, stucco mihrab, known as the Ankara Style.

The basic approach in conservation practices should be based on a holistic approach comprising the immovable cultural property and its surrounding. Within the scope of conservation studies, survey studies, historical researches, reports and subsequently restitution project, periodization, analyzes of material and damage; and restoration projects are created for immovable cultural assets that need to be protected. Elimination of the factors that pose risks to the historical structure, structural and material problems is the main intervention of the conservation studies. The intervention should not cause irreversible results, therefore preliminary studies should be carried out by the conservation experts before active conservation application. As a result of the 
analyzes and evaluations made by experts, the correct method should be determined and the suggested methods should be tested with experimental applications.

The deterioration in the physical integrity of the building is directly related to the deterioration of building materials. The main causes of deterioration in materials are the material itself, the materials that is adjacent to, the environment, and the interventions that the authentic material has been exposed to. The important thing is the practices that will be carried out without damaging the authentic materials and avoiding misleading perception. It is an essential practice to renew and replace materials that have lost their functional and physical integrity. Since cleaning process is a direct application to the surface of the material, it is necessary to choose a method that does not deteriorate the original material, not cause structural weakness, and not allow new problems such as salting or staining on the surface. During the cleaning method selection, the type of material to be cleaned, its protection status, the characteristics of the dirt layer and the width of the surface would play a decisive role. Wet cleaning methods such as nebulization, steam cleaning, absorbent clays packaging and chemical packaging, and dry cleaning methods such as mechanical cleaning, laser cleaning and controlled micro sandblasting are the main cleaning methods. An important study in the preparation phase of the projects is the analysis of materials. The physical and chemical properties of the materials, changes and deterioration on the materials would be determined through material analysis and archaeometric studies on-site with non-destructive methods. Undoubtedly, an interdisciplinary work is needed in order to achieve healthy results in conservation science.

In addition to active protection, preventive protection should also be applied. Elimination of factors such as moisture problems (rain water, rising humidity, condensation) that cause deterioration would prevent new deteriorations in the future. Protective material to be applied to the material surface would provide physical and chemical protection that would reduce the penetration of water, salt or acid through the material. The life of the material should be extended with periodic maintenance and sustainable restoration applications.

Zincirli Mosque is a 17th century mosque in Ulus District, Altındağ, Ankara, which was built in Ankara Style. Zincirli Mosque, whose construction date goes back to the 17th century, has undergone numerous repairs in the 19th, 20th and 21st centuries and is now open to worship. The area is impor- 
tant because of the surrounding immovable cultural heritage from the Roman, Ottoman and Republic periods. The mosque and its surrounding should be evaluated in a holistic manner and the values of this environment should be perceived correctly.

It is understood that the mosque has undergone periodic maintenance due to its still being used. The facade of the mosque was completely changed during the restoration works in 1937. The courtyard, which was transformed into an indoor space due to the climatic conditions and in order to increase the capacity of the community, damaged the authenticity of the mosque's environment. However, due to the fact that these applications are necessity and removable, they could be kept in this way. The wooden elements and the plasters on the facade has been deteriorated as a result of faulty applications such as many layers of painting and varnishes.

Within the conservation of the mosque, deteriorations because of environmental factors like temperature, relative humidity, climatic conditions; and deteriorations due to human factors were defined; required types of interventions and measures were proposed to prevent new deteriorations. Within the scope of conservation studies, it is necessary to determine the correct method as a result of laboratory analyzes and reports and to test the proposed methods with experimental applications. In this study based on visual analysis, protection recommendations were made especially for material deterioration. With the proposed material conservation studies, it is possible to examine the current state of the building, to investigate and determine the factors of deterioration and to intervene them. Before these applications, documentation, history and restitution studies and projecting the restoration should be carried out according to scientific principles.

\section{Kaynakça/References}

Ahunbay, Z. (2009). Tarihi çeore koruma ve restorasyon. İstanbul: Yapı Endüstri Merkezi Yayınları.

Akpolat, M.S. ve Eser, E. (Editörler). (2004). Ankara: başkentin tarihi, arkeolojisi ve mimarisi. Ankara: Ankara Enstitüsü Vakfı Yayınları.

Aktüre, S. (1994). 17. ve 18. yüzylllarda Ankara. E. Batur (Editör). Ankara Ankara içinde (s. 911-917). İstanbul: Yapı Kredi Yayınları.

Ceylan, C. ve Aydın, Ö. (2018). 18.-19. yüzyıl Ankara camileri üzerine bir değerlendirme. Journal of Social Sciences and Humanities, 2, 1-21.

English Heritage. (2012). Practical building conservation: Stone. London: Ashgate Publishing Company. 
Erdoğan, A., Günel, G. ve Kılcl, A. (2007a). Tarih içinde Ankara. Ankara Tarihi ve Kültürü Dizisi 1, Ankara: Ankara Büyükşehir Belediyesi, Kültür ve Sosyal İşler Dairesi Başkanliğı.

Erdoğan, A., Günel, G. ve Kılcı, A. (2007b). Osmanlı'da Ankara. Ankara Tarihi ve Kültürü Dizisi 2, Ankara: Ankara Büyükşehir Belediyesi, Kültür ve Sosyal İşler Dairesi Başkanliğı.

Erdoğan, A. ve Narince, M. (2007). Edebi ve tarihi şahsiyetleriyle Ankara. Ankara Tarihi ve Kültürü Dizisi 6, Ankara: Ankara Büyükşehir Belediyesi, Kültür ve Sosyal İşler Dairesi Başkanlığ1.

Ergenç, Ö. (1980). XVII. yüzyılın başlarında Ankara'nın yerleşim durumu üzerine bazı bilgiler. Osmanh Araştırmaları, 1, 85-108.

Ersen, P. , Güleç, D. , Alkan, K. ve Kudde, E. (2009). Konservasyon raporunun önemi, içeriği ve hazırlanma adımları. Restorasyon ve Konservasyon Çalışmalan Dergisi, 2, 3-16.

Eskici, B. (1997). Taş eserlerin korunması üzerine notlar. Türk Arkeoloji Dergisi, 31, 383-392.

Eskici, B. (2001). Ankara mihrabları, Ankara: Kültür Bakanlığı Yayınları, Başbakanlık Basımevi.

Eskici, B. (2008). Mimari restorasyonda malzeme kullanımı ve yöntem sorunları üzerine. Yapr Dergisi, 322, 118-123.

Eskici, B. (2009). Tarihi bina onarımlarında cephe temizliğinin önemi ve yöntem sorunları üzerine. Tarihi Eserlerin Güçlendirilmesi ve Geleceğe Güvenle Devredilmesi Sempozyumu 2 içinde (s. 773-784). Ankara, TMMOB İnşaat Mühendisleri Odası.

Eyice, S. (1971). Ankara'nın eski bir resmi. Atatürk Konferansları IV, Ankara: Türk Tarih Kurumu Yayınları, XVII. Seri, s. 112.

Hasdemir, İ. (2014). Tarihi yapılarda pencere camı restorasyonu. Restorasyon ve Konservasyon Çalışmaları Dergisi, 13, 60-64.

Kırpık, G., Erdoğan, A. ve Çam, M. (2015). Şehr-i kadim Ankara. Cilt 2, Ankara: Ankara Büyükşehir Belediyesi, Basın Yayın ve Halkla İlişkiler Dairesi Başkanlığı.

Kırpık, G., Erdoğan, A., Çam, M., Kılcı, A., Topraklı, A. Y. (2015). Şehr-i kadim Ankara. Cilt 3, Ankara: Ankara Büyükşehir Belediyesi. Basın Yayın ve Halkla İlişkiler Dairesi Başkanlığı.

Konyalı, İ. H. (1978). Ankara camileri. Ankara: Kültür Matbaacllı.

Küçükkaya, A. G. (2004). Taşların bozulma nedenleri ve koruma yöntemleri. İstanbul: Birsen Yayınevi.

Kültür ve Turizm Bakanlığı. (2019, 9 Eylül). Zincirli Camii. https://www.kulturportali.gov.tr/turkiye/ankara/gezilecekyer/zincirli-camii-1 adresinden erişilmiştir.

Öney, G. (1971). Ankara'da Türk devri yapıları. Ankara: Ankara Üniversitesi Dil-Tarih ve Coğrafya Yayınları.

Öney, G. (1992). Anadolu Selçuklu mimarisi süslemesi ve el sanatları. Ankara: Türkiye İş Bankası Kültür Yayınları.

Nazire P. S. (2010). Ahşap malzeme sorunlarının teşhis yöntemleri. Restorasyon ve Konservasyon Çalısmalan Dergisi, 4, 81-87. 
Şener, Y. S. (2015). Taş eser korumada tamamlama uygulamaları: yöntem ve uygulama biçimlerine ilişkin değerlendirmeler. IV. ODTÜ Arkeometri Çalıştayı, Türkiye Arkeolojisinde Taş: Arkeolojik ve Arkeometrik Çalışmalar içinde (s. 143-151). Ankara: Bilgin Kültür Sanat Yayınları.

Tapan, M. (2007). Soru ve cevaplarla koruma. İstanbul: Mimarlar Odası İstanbul Büyükkent Şubesi.

Taşkan, D. (2016). Ankara (merkez) cami ve mescitlerindeki ahşap tavan göbekleri [Özel Say1]. Gazi Üniversitesi Sosyal Bilimler Dergisi, 71-101.

Tunçer, M. (2001). Ankara (Angora) şehri merkez gelişimi (14.-20.yy). Ankara: Kültür Bakanlı̆̆ı Yayınları.

Vakıflar Genel Müdürlüğü [VGM]. (2019). Dijital Arşiv. Ankara.

Yaman, Y. (Editör). (1981). Ankara. Yurt Ansiklopedisi: Türkiye, İ İl: Dünü, Bugünü, Yarmı, 1, İstanbul: Anadolu Yayıncllk, s. 510-712.

Yüksel, A. E. (2016). Ankara cami ve mescitlerinde Ankara üslubu. Journal of History and Future, 2 (1), 154-177. 